\title{
Histone H2B Type 1-H
}

National Cancer Institute

\section{Source}

National Cancer Institute. Histone H2B Type 1-H. NCI Thesaurus. Code C162939.

Histone H2B type 1-H (126 aa, $14 \mathrm{kDa}$ ) is encoded by the human H2BC9 gene. This protein plays a role in the modulation of histone-dependent cellular processes. 